\begin{tabular}{|l|l|l|}
\hline \multicolumn{2}{|c|}{ PublisherInfo } \\
\hline \hline PublisherName & $:$ & BioMed Central \\
\hline \hline PublisherLocation & $:$ & London \\
\hline \hline PublisherImprintName & $:$ & BioMed Central \\
\hline \hline
\end{tabular}

\title{
Modeling miRNA mechanisms
}

\begin{tabular}{|l|l|l||}
\hline \multicolumn{2}{|c|}{ ArticleInfo } \\
\hline \hline ArticleID & $:$ & 4845 \\
\hline \hline ArticleDOI & $:$ & $10.1186 /$ gb-spotlight-20030925-02 \\
\hline \hline ArticleCitationID & $:$ & spotlight-20030925-02 \\
\hline \hline ArticleSequenceNumber & $:$ & 197 \\
\hline \hline ArticleCategory & $:$ & Research news \\
\hline ArticleFirstPage & $:$ & 1 \\
\hline \hline ArticleLastPage & $:$ & 3 \\
\hline \hline & & RegistrationDate : 2003-9-25 \\
\hline ArticleHistory & $:$ & OnlineDate \\
\hline \hline ArticleCopyright & $:$ & BioMed Central Ltd2003-9-25 \\
\hline \hline ArticleGrants & $:$ & \\
\hline \hline ArticleContext & $:$ & 130594411 \\
\hline \hline
\end{tabular}


Small, noncoding RNA molecules mediate a posttranscriptional gene-silencing mechanism that regulates the expression of developmental genes by inhibiting the translation of target mRNAs. This mechanism is common to plants, fungi, and animals, and the generation of these microRNAs (miRNAs, also known as small inhibitory RNAs or siRNAs) involves a series of sequential steps, where primary RNA transcripts (pri-miRNAs) are cleaved in the nucleus to smaller pre-miRNAs. These are transported to the cytosol where Dicer, a member of the RNAse III nuclease family, further processes them to yield mature miRNAs. MiRNAs associate with multicomponent ribonucleoprotein complexes, or RISCs, which effect the silencing of the target mRNA molecules. Two papers in the September 25 Nature report previously unidentified key components in the miRNA regulatory system. Yountae Lee and colleagues at Seoul National University identify a protein that cleaves pri-miRNAs to pre-miRNAs, while Amy Caudy and colleagues at Cold Spring Harbor Laboratoryidentify another component of the RISC complex.

Lee et al. cloned and sequenced the sites of cleavage of the miRNA miR-30a, revealing a stem-loop structure with a two-nucleotide overhang suggestive of the mechanism of action of another RNAse III family member. The authors then focused on the candidate protein Drosha, because of its nuclear location and role in preribosomal RNA processing. Immunopurified Drosha cleaved pri-miRNAs in vitro, while its knockout (by Drosha-specific miRNA interference) resulted in the accumulation of primiRNAs and a depletion of the mature product. Examining the action of Drosha with Dicer revealed a synergistic role of these two nucleases in the accurate generation of specific miRNAs (Nature, DOI:10.1038/nature01957, September 25, 2003).

"Our study introduces a new player in miRNA biogenesis. It is an open question how Drosha and Dicer recognize their targets in a specific manner when the primary sequences of diverse miRNAs show no conserved elements. In view of this, it will be important to determine structures of miRNA precursors and RNase III proteins," conclude Lee and colleagues.

Caudy et al. purified a RISC complex from Drosophila and identified its protein and RNA components. They identified an evolutionarily conserved $103-\mathrm{kDa}$ protein containing five repeats of a staphylococcal/micrococcal nuclease domain, with the fifth domain fused to a tudor domain - hence the name Tudor-SN. The authors also identified this molecule in RISCs from Caenorhabditis elegans and mammals with similar functional activity to other staphylococcal nucleases and showed that a specific competitive micrococcal nuclease inhibitor inhibited both Tudor-SN and RISCs (Nature, DOI:10.1038/ nature01956, September 25, 2003).

"Our data strongly indicate that Tudor-SN is a bona-fide RISC component. It is certainly consistent with our biochemical data to suppose that RISC contains multiple nucleases, only one of which... can catalyze site-specific mRNA cleavage. In this scenario, Tudor-SN might act to degrade the remainder of the mRNA," conclude Caudy and colleagues. 


\section{References}

1. RNA-mediated gene silencing

2. Nature, [http://www.nature.com/nature]

3. Seoul National University, [http:/www.snu.ac.kr:6060/engsnu/index.html]

4. Cold Spring Harbor Laboratory, [http://www.cshl.org]

5. Assembly of the Drosophila germ plasm

This PDF file was created after publication. 